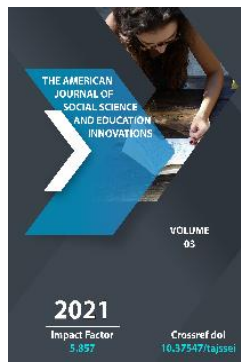

\title{
Impact Of Natural Sciences On The Philosophical Worldview In The Antiquity
}

\author{
Pardaev Sultonmurod \\ Doctoral Student At The Department Of Philosophy And The Basics Of Spirituality Of The \\ National University Of Uzbekistan
}

Journal Website:

https://theamericanjou

rnals.com/index.php/ta

jssei

Copyright: Original content from this work may be used under the terms of the creative commons attributes 4.0 licence.

\section{ABSTRACT}

The article explains the origin of natural sciences and their basic concepts, the essence of natural sciences, the existing natural sciences, the history of the formation of natural sciences and their peculiarities in philosophical terms.

\section{KEYWORDS}

Scientific knowledge, natural knowledge, existence and non-existence, the evolution of naturalscientific knowledge, ontological understanding, the nature of natural-scientific knowledge and their status.

\section{INTRODUCTION}

In the early stages of human development, ignorance of nature and natural phenomena led to the formation of fear in the minds of mankind. Therefore, in ancient Roman, Greek, Roman and Chinese myths, natural creatures: earth, water, air, sun, moon, stars and natural phenomena occurring in the environment: solar and lunar eclipses, hurricanes, heavy rain, flood, thunder, lightning, hail, earthquake, volcanic eruption, landslide, drought, forest fires, plagues considered. They thought that the wrong attitude of the people towards them would lead to the wrath of the gods to the mankind, which would lead to various calamities for the people. They worshiped them to get rid of them.

The occurrence of natural phenomena was understood as a response to the wrong attitude (reflection) of humanity towards 
nature. Although these conclusions were born out of fear of nature, they also had a scientific basis. ${ }^{1}$ Nature has a long history. Knowledge of nature has met many human needs. In particular, this knowledge served to understand the environment, to determine the connection between cycles and events in nature and social life processes, to record and establish the connection between the sequence of seasons and historical traditions. The archaic (i.e., oldest) knowledge of nature has not yet emerged from the shell of mythological consciousness. However, man at that time had little knowledge of the processes of nature. Orphans and a number of other mythological and philosophical teachings seek to correct and purify the traditional religious beliefs of the Greeks. At the same time, Thales, Anaximenes, and Anaximander, members of a school called Ionian natural philosophy, advanced completely different naturalscientific views in philosophy. These philosophers were the first to describe the universe as a harmoniously structured, selfevolving, self-governing system.

Ancient Greek philosophy originated in Greece in the $6^{\text {th }}$ century BC. As a result of economic growth and the development of trade, there have been significant shifts in cultural and educational life. The state emerged, law, art and literature were formed, and trade increased. Also, the natural sciences, especially physics, mathematics, astronomy, geography, began to take shape, which laid the foundation for the development of philosophical thought. The first philosophers of ancient Greece were thinkers who tried to imagine the origin of the earth, the sun, the stars, the animals, and man as a whole. That is why they are called "physicists".2 These thinkers fought against religion and idealism as representatives of the progressive strata of the Greek slave class. Ancient Greek materialism entered the field of ideology in close connection with the natural

\footnotetext{
${ }^{1}$ E.O.Turdiqulov „Markaziy Osiyoda ekologik ta'lim taraqqiyoti" Toshkent.2013-yil 14-b.
}

sciences acquired in the countries of the ancient East and Greece. For this reason, Greek philosophers were at the same time merchants, travelers, politicians, and all-round naturalists. It was clear that the first philosophers were inevitably faced with the question of what was the first invention of all things. According to Thales and Anaximenes, everything must have been one of the four phenomena of nature, the primary ore from which it came into being and which again became it. Thales gave preference to water, while Anaximenes gave priority to air. But Anaximander was ahead of everyone else in the field of passive theoretical understanding of natural phenomena. He declared that the first basis and cause of all existence is the infinite apeiron. Apeiron is an eternal and infinite ore that cannot be qualitatively linked to any of the four natural phenomena, and yet it is in constant motion. In the process of continuous motion, heat and cold, dryness and humidity, which are the opposite origins, are released from the apeiron. Pairs of opposites interact to create both living and dead phenomena of nature. According to Anaximander, everything originates from the apeiron and returns to the apeiron at a certain time. Apeiron's constant motion, according to Anaximander, is due to the origin of contradictions, as a result of which the same things appear and the others disappear. The existence of these things in the world does not need any gods. Anaximander was one of the scientists who tried to prove the origin of man in ancient Greek science. According to him, the fauna originated under the dried sea, and the first animals lived in the water, then came ashore, and humans evolved from fish.

The next representative of the school of Miletus is Anaximenes. According to Anaximenes, all things arise from air in constant motion and return to air again. Sparse, condensed air turns into fire,

\footnotetext{
2 Karimov I. Rustamova M , Falsafa fani tarixi va nazariyasi" T,. 2007-yil.49-b.
} 
condensed air turns into earth, stone. The air, according to Anaximenes, condenses from the cold and liquefies from the heat. ${ }^{3}$ Greek philosophers were well aware that experience, experimental research, and observation serve as the most fundamental of all knowledge. In essence, they were not only the first philosophers, but also the first scientists who were the founders of Greek and all-European science. The ancients called Thales "the first mathematician", "the first astrologer", "the first physicist". Using earlier discoveries by Babylonian astrologers, Thales predicted a possible solar eclipse in $585 \mathrm{BC}$. He proved several geometric theorems in the first part, introducing a compass and an angle gauge. ${ }^{4}$ Thales also visited many countries and was closely acquainted with the culture, science, and philosophical heritage of these countries (including Egypt and Babylon). He predicted a solar eclipse a few years ago. Thales said the cause of the solar eclipse was that the Moon blocked the path of the Sun. He says that the light of the moon is a reflection of sunlight on the moon. He also proved that the motion of the sun for a year is equal to 365 days. Historical sources state that Thales discovered the Ursa Minor (The Lesser Bear) constellation. He also predicted the weather. He also studied geometry. In particular, it is said that he dealt with the problem of equality of angles. According to Thales, various bodies and phenomena in nature originated from the first liquid substance, water. Eventually all bodies composed of water become water. According to Thales, the earth also came from water. The ground is round, flat, and surrounded by water. Water is the sole and constant material basis of the infinite, diverse bodies and phenomena in the universe, their constant motion and change. Water is eternal, but the bodies and events that result from it are temporary and transient. He was the first to state the material

\footnotetext{
3 Zoxidov I.R ,, Fakultetlaraoro falsafa” Samarqand ,. 2010-yil.168-169-b.

${ }^{4}$ Ahmedova M. „Falsafa “ T.,.2006-yil.62-b.
}

unity of the universe, and that this material unity is constantly changing. Thales misinterpreted the cause of the properties of water and the resulting objects, such as motion and change, and concluded that they had a soul. For example, he says that a magnet is a living thing, so it attracts iron. His idea provided an opportunity for an idealistic understanding of the world. Thus, Thales developed the Hylozoist doctrine. Aristotle wrote about this in his book On the Soul: "Thales said that the soul is mobile, which means that it moves magnetic iron, which means that iron also has soul."

Thales also tried to determine the structure and order of the universe around the earth. He relied on Babylonian astronomy to determine the position of celestial bodies relative to the earth, but Thales explained the position of celestial bodies relative to the earth in a way that was contrary to actual teaching. "The nearest stationary stars to Earth and the farthest sun," he said. His mistake was corrected by his disciples Anaximander and Anaximenes. ${ }^{5}$ The center of Ionian philosophy after Miletus was the city of Ephesus, the birthplace of the philosopher Heraclitus. Heraclitus saw the primary element of the world in fire. The significance of Heraclitus in the history of philosophy was that he explained the question of the law of necessity inherent in matter in relation to the state of dialectical development of the world. The dialectical unity of opposites is expressed by Heraclitus in such a way that they always complement each other in harmony and emerge in this way. The significance of Heraclitus' teaching is that he recognized his idea of the materiality of the world as a legitimate process, such as the change of things and events. Heraclitus describes the eternal and most general law as Logos. ${ }^{6}$ The most famous philosophical school in southern Italy was the Pythagorean school.

\footnotetext{
5 Yo'ldoshev S.A ,, Antik falsafa “' T., 1999-yil .15-16bb.

6 Karimov I. Rustamova M , Falsafa fani tarixi va nazariyasi" T,. 2007-yil.50-b.
} 
The Pythagoreans were an enemy of democracy, isolated from the masses, wrapped in their own shells. Their mystical teachings were subtler taboos and cured of mental superiority. Pythagoras and his followers were interested in mathematical calculations, interpreting the combination of numbers and figures in a mysterious spirit. According to Pythagoras, the basis of the world is numbers, numbers are an expression of the order in the universe. To know the world is to know the numbers that govern it. Although the Pythagoreans separated numbers from matter and deified it, they did make a significant contribution to the formation of the science of mathematics. The result was the famous Pythagorean theorem. The most prominent representatives of materialism in this period were Anaxagoras and Empedocles. According to Anaxagoras, it was originally a motionless alloy composed of the smallest particles ("seeds") that the reason (nous) gave it motion. Anaxagoras' teaching on the mind meant a sharp contrast between the source of motion of inactive matter. This had a profound effect on the subsequent development of philosophical thought (the idea of the "first impulse" of modern philosophy). Empedocles saw the four primary elements underlying everything: fire, air, earth, and water. According to Empedocles, all things are made up of four elements, which do not change in quantity or quality, but are joined together in different proportions. Aristotle's acceptance of the theory of the four elements served as the basis of European physics until the seventeenth century. ${ }^{\text {? }}$

In ancient Greece, materialism reached its peak during the reigns of Leucippus and Democritus. It should be noted that the development of natural sciences on the basis of their philosophical teachings has further developed. Because they imagined the whole being to come from objects in nature. From this it can be said that their natural-scientific views later served as the starting point for new natural and scientific sciences. Leucippus, a representative of atomism, founded the philosophy of atomism. His disciple Democritus polished it and brought it into his own system. According to this theory, the world is made up of atoms in space and motion, that is, infinitely small indivisible particles that do not change qualitatively the same, but differ in shape and pattern. Atoms move in space, and when they join together, they form the whole universe. $A$ living being is different from a non-living thing in that it has a soul. The soul is made up of atoms moving in a circle. Democritus considered the soul to be something that dies. When the body dies, the atoms scatter into space. The most important rule in the teachings of Democritus is the view of action, which is presented as an integral feature of this substance and is inherent in it. ${ }^{8}$

Economic, political, and ideological cooperation with European states in ancient Egypt and Babylon began in ancient China long before India. The first philosophical ideas in these countries are connected with the development of world sciences - astronomy, cosmology, mathematics, mythology. Philosophical science as a separate form of social thought was not yet separated in Egypt and Babylon. In the third millennium BC, slavery was established in Egypt and Babylon. In these countries, slave labor was used to dig ditches and ditches, irrigate lands, and build pyramids, temples, and palaces. The cultural heritage of ancient Egypt and Babylon dates back to the fourth millennium BC. Ancient Babylonian literature also contained sources criticizing oppression and belief in gods and the afterlife. One such work is The Master's Dialogue on the Meaning of Life with His Slave. It reflects the idea that it is impossible to hope for the mercy of the king, to fight against the tyrant without success. It turns out that the sun is the power that extinguishes the light of the sky. The sun was considered the source of

${ }^{8}$ Ahmedova M. „Falsafa “ T.,.2006-yil.65-b.
7 Ahmedova M. „Falsafa “' T.,.2006-yil.64-b. 
darkness, the power of the underworld, and the sun as the ambassador of death. But when the moon dies, it gives new life, so it is a symbol of eternal, unending life. It is said that there is a dark place under the ground where the dead live. Researchers say that the images and legends created during the primitive community reflected the astronomical, biological, and mathematical knowledge of the ancients, and gave accurate representations of objects in nature, albeit in a unique form. In the ancient kingdom of Babylon there were manuals on the rules of law, botany, medicine, mineralogy, preparation of chemical medicines. Historians call the natural sciences developed in ancient Egypt "proto-science" or "early science." According to them (Dyakonov, Orastosev, etc.), without such knowledge, there would be no real science with human methods, concepts and problems. The science of nature, created in the ancient Eastern civilizations, did not rise above the emotional, empirical form and level, but was mainly prescription, that is, algorithmic in the form of performing a certain result, solution step by step, sequence of actions. ${ }^{9}$ When we briefly study the history of philosophy in the countries of the Ancient East, we see that the naturalscientific ideas of the peoples of the Ancient East have their own characteristics. In ancient China, for example, science and culture began to develop in a unique way. By the second half of the second millennium BC, a slave economy had emerged in the Shan-in state. At that time, blood relatives played an important role in farming. The members of the team have worked in the state. By the twelfth century BC, the Shan state had fallen to the Zhou tribe as a result of wars. This authority ruled until the 3 rd century $B C$ and the system of slavery was strengthened. Slaves were now engaged not only in animal husbandry and farming, but also in canal digging and handicrafts. At the same time, a religious-mythological worldview prevailed. In ancient Chinese mythology, the origin of the universe and nature was explained in a unique way. That is, in ancient times, when the universe was a dark, formless space, two souls were born in formless darkness. One was Yin and the other was Yan, who was involved in organizing the world. These spirits were later divided: the spirit of Yan ruled the heavens and the spirit of In ruled the earth. According to historical sources, these spirits created humans. Animals, fish, and insects emerged from the rough parts of the darkness. According to other legends, man was created by the goddess Fusi and the goddess New-Wei. All the history of ancient philosophy testifies that during the reign of the tribal community, it influenced the formation of scientific knowledge. In particular, natural philosophical ideas were central to ancient Chinese philosophy. Confucius also regarded the sky as a terrifying whole, and regarded it as a divine power, a human form. The will of heaven is destiny. The world under heaven, that is, the order on earth, must be determined by law.

\section{REFERENCES}

1. Turdiqulov.E.U. Markaziy Osiyoda ekologik ta'lim taraqqiyoti. T.: 2013

2. Karimov I. Rustamova M. Falsafa fani tarixi va nazariyasi. T.: 2007

3. Zoxidov I.R . Fakultetlaraoro falsafa. S.: 2010

4. Ahmedova M. Falsafa. T.: 2006

5. Yo'ldoshev S.A. Antik falsafa. T.: 1999

9 N.A.Shermuhamedova " Tabiatshunoslik falsafasi", Toshkent.2017-yil 28-b. 